\title{
Prevalence of postural deviations and associated factors in children and adolescents: a cross-sectional study
}

\author{
Prevalência de variações posturais e fatores associados \\ em crianças e adolescentes: um estudo transversal
}

\author{
Mariana Vieira Batistão, Roberta de Fátima Carreira Moreira, Helenice Jane Cote Gil Coury, Luis \\ Ernesto Bueno Salasar, Tatiana de Oliveira Sato*
}

Universidade Federal de São Carlos, (UFSCar), São Carlos, SP, Brazil

\begin{abstract}
Introduction: Postural deviations are frequent in childhood and may cause pain and functional impairment. Previously, only a few studies have examined the association between body posture and intrinsic and extrinsic factors. Objective: To assess the prevalence of postural changes in school children, and to determine, using multiple logistic regression analysis, whether factors such as age, gender, BMI, handedness and physical activity might explain these deviations. Methods: The posture of 288 students was assessed by observation. Subjects were aged between 6 and 15 years, 59.4\% ( $n=171)$ of which were female. The mean age was $10.6( \pm 2.4)$ years. Mean body weight was $38.6( \pm 12.7) \mathrm{kg}$ and mean height was $1.5( \pm 0.1) \mathrm{m}$. A digital scale, a tapeline, a plumb line and standardized forms were used to collect data. The data were analyzed descriptively using the chi-square test and logistic regression analysis (significance level of 5\%). Results: We found the following deviations to be prevalent among schoolchildren: forward head posture, 53.5\%, shoulder elevation, $74.3 \%$, asymmetry of the iliac crests, 51.7\%, valgus knees, 43.1\%, thoracic hyperkyphosis, 30.2\%, lumbar hyperlordosis, $37.2 \%$ and winged shoulder blades, $66.3 \%$. The associated factors were age, gender, BMI and physical activity. Discussion: There was a high prevalence of postural deviations and the intrinsic and extrinsic factors partially explain the postural deviations. Conclusion: These findings contribute to the understanding of how and why these deviations develop, and to the implementation of preventive and rehabilitation programs, given that some of the associated factors are modifiable.
\end{abstract}

Keywords: Disease Prevention. Low Back Pain. Posture.

*MVB: Doctoral student, e-mail: marivbatistao@gmail.com

RFCM: PhD, e-mail: roberta.carreira@gmail.com

HJCGC: PhD, e-mail: helenice@ufscar.br

LEBS: PhD, e-mail: luis.salasar@gmail.com

TOS: PhD, e-mail: tatisato@gmail.com

Fisioter Mov. 2016 Oct/Dec;29(4):777-85 


\section{Resumo}

Introdução: Variações posturais são frequentes na infância e podem causar dor e prejuízo funcional. Embora a prevalência de variações posturais em crianças já tenha sido avaliada, poucos autores investigaram a associação entre a postura e fatores intrínsecos e extrínsecos. Objetivo: Avaliar a prevalência de variações posturais em crianças e adolescentes e identificar fatores explicativos para estas variações, dentre eles: idade, gênero, dominância manual, índice de massa corporal (IMC) e atividade física, por meio da análise de regressão logística múltipla. Métodos: A postura de 288 estudantes foi avaliada de forma observacional. Os sujeitos tinham idades entre 6 a 15 anos, sendo 171 (59,4\%) do sexo feminino. A idade média foi de 10,6 (2,4) anos, massa corporal de 38,6 (12,7) kg e altura de 1,5 (0,1) m. Utilizou-se balança digital, fita métrica, fio de prumo e formulários padronizados. Os dados foram analisados descritivamente, com o teste de Qui-quadrado e regressão logística (nível de significância - 5\%). Resultados: A prevalência de anteriorização da cabeça foi de 53,5\%; elevação do ombro 74,3\%; assimetria entre as cristas ilíacas 51,7\%; joelhos valgos 43,1\%; hipercifose torácica 30,2\%; hiperlordose lombar 37,2\% e $66,3 \%$ de escápulas aladas. Os fatores associados foram idade, sexo, IMC e não realização de atividade física. Discussão: A prevalência de variações posturais foi alta. Os fatores escolhidos explicam parcialmente as variações posturais. Conclusão: Esses achados contribuem para a compreensão do desenvolvimento destas variações e para a proposição de programas preventivos e de reabilitação, considerando que entre os fatores analisados, alguns são modificáveis.

Palavras-chave: Prevenção de Doenças. Dor Lombar. Postura.

\section{Introduction}

Good posture is a state of equilibrium of body segments, in a position of least effort and maximum support $(1,2)$. In children, whole body posture is influenced by physical development, which depends on nutritional, congenital and environmental factors (1).

Many postural deviations originate in childhood and adolescence (2). Some of them are common in children of the same age group and are considered to be a response of the body to the demands of gravity $(3,4)$. They are usually corrected spontaneously with the development of muscle strength $(1,5,6)$. However, if they persist, they will lead to joint overload, causing discomfort and functional impairment (3).

According to several studies, common postural deviations found in at least $50 \%$ of healthy children include poor formation of the longitudinal arch of the foot; knee hyperextension and valgus; medial rotation of the hip; pelvic anteversion; pelvic tilt; abdominal protrusion; lumbar hyperlordosis; winged shoulder blades; protruding shoulders; thoracic hyperkyphosis; and shoulder elevation $(1,3,5,7,8,9,10)$.
It is important to diagnose postural deviations in children, because their skeletal system is still susceptible to changes and poor posture is more easily corrected at this stage of development $(11,12)$. Thus, postural assessment should become a common practice in schools, in order to early detect and treat postural deviations in students (4). Besides this, schools have the potential to develop children's knowledge and skills and to help them learn how to live a healthy life $(13,14)$.

Postural assessment is a complex procedure, because it takes into account many intrinsic and extrinsic factors that can influence an individual's posture, such as the environment, his/her social, cultural and emotional status, physical activity, obesity, physiological developmental disorders, sexual maturation, gender and heredity (15).

Although many authors have investigated the prevalence of postural deviations in children, only few studies have examined the association between body posture and intrinsic and extrinsic factors. Arruda (16) has studied the association between postural deviations and obesity in children aged 8-10 years. Detsch e Candotti (4) have found an association between age and postural deviations in girls. 
Detsch et al. (3) have studied the association between the postural deviations and type of school (public or private), parental education, age, body mass index (BMI) and body postures adopted in everyday situations. Penha et al. (9) have studied the association between age and postural deviations. However, the aforementioned studies have only used association tests. Multiple logistic regression analysis, which allows the simultaneous assessment of multiple factors and can help understand the influence of these factors upon postural deviations, has not been reported.

Thus, the objectives of this study were to determine the prevalence of postural deviations in schoolchildren aged 6 - 15 years, and to identify, using multiple logistic regression analysis, whether factors such as age, gender, BMI, hand dominance and physical activity are associated with these deviations.

\section{Methods}

Subjects and study site

All 1st to 8th graders from a public school in São Carlos, SP, Brazil, were invited to participate in the study. The selection criteria were: 1 . formal consent from a parent or legal guardian; 2. being in good health at the time of the investigation; and 3. no detected or reported neuromuscular, rheumatic or metabolic disorders.

Three hundred and four (41.3\%) of a total of 739 students enrolled at the school returned a signed consent form and were then assessed. Of these, 16 were excluded because they did not complete the assessment procedures. Thus, the final sample consisted of $288 \mathrm{stu}-$ dents whose characteristics are depicted in Table 1.

Table 1 - Participants' Anthropometric Data (mean \pm standard deviation)

\begin{tabular}{|c|c|c|c|}
\hline Gender & $\begin{array}{c}\text { Female } \\
(n=171)\end{array}$ & $\begin{array}{c}\text { Male } \\
(n=117)\end{array}$ & $\begin{array}{c}\text { Total } \\
(\mathrm{N}=288)\end{array}$ \\
\hline Age (years) & $10.6 \pm 2.4$ & $10.5 \pm 2.6$ & $10.6 \pm 2.4$ \\
\hline $\begin{array}{l}\text { Body mass } \\
(\mathrm{kg})\end{array}$ & $39.1 \pm 12.3$ & $38.0 \pm 13.2$ & $38.6 \pm 12.7$ \\
\hline Height (m) & $1.5 \pm 0.1$ & $1.5 \pm 0.2$ & $1.5 \pm 0.1$ \\
\hline $\begin{array}{c}\text { Body mass } \\
\text { index }(\mathrm{kg} / \\
\left.\mathrm{m}^{2}\right)\end{array}$ & $18.2 \pm 3.5$ & $17.5 \pm 3.0$ & $17.9 \pm 3.3$ \\
\hline
\end{tabular}

This study met the criteria established by Resolution 196/96 of the National Health Council and was approved by the Research Ethics Committee of the Federal University of São Carlos (CAAE 0124.0.135.000-08, opinion 039/2009).

\section{Equipments}

The following equipments were used in this study: plumb line, rotating platform, tapeline (with an accuracy of $5 \mathrm{~mm}$ ) and digital scale (G Life ${ }^{\circledR}$, maximum $180 \mathrm{~kg}$ with an accuracy of \pm 100 gram).

\section{Procedures}

The researchers completed a questionnaire with personal information such as age, gender, handedness and physical activity, based on the students' self-reports. After the interview, the children were asked to change into bathing suits, so that the weight of their clothes was not added to their weight and we could get a better visualization of their body segments. Students' weight and height measurements were then collected. Body mass was measured using a digital anthropometric scale, while height was measured to the nearest $5 \mathrm{~mm}$ with a tapeline.

For the postural assessment, the children were asked to step onto a rotating platform in front of one of the researchers. Their feet should be about hipwidth apart and pointing straight ahead. Students were instructed to stand still in a relaxed posture, looking forward. A researcher rotated the platform in order to prevent changes in position due to movement by the subjects. Figure 1 shows a subject standing on the platform.
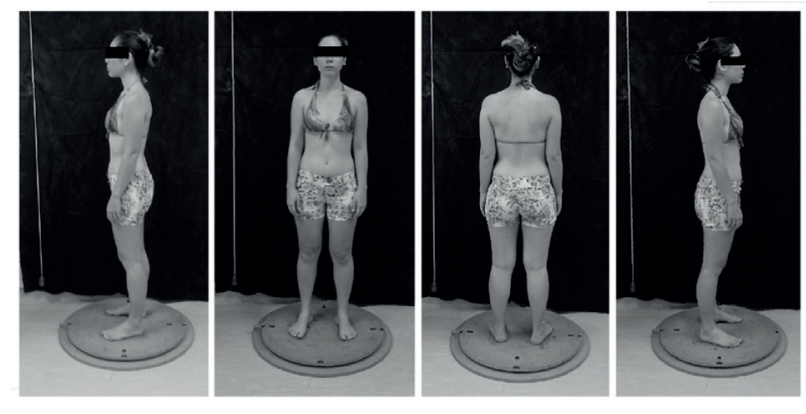

Note: Source: authors.

Figure 1 - Student standing on the rotating platform and beside a plumb line for postural assessment. 
Postural Assessment

When assessing posture, direct (quantitative) measurements are comparatively more accurate than subjective (qualitative) measurements (17). Direct measurement methods include radiography and software-based measuments (such as the ones using the Postural Assessment Software [PAS/SAPO]). However, these types of assessments are more complex, more time consuming, and restricted to certain body parts (PAS/SAPO) and expose the subject to radiation (radiography) $(18,19)$.

Qualitative assessment is more widely used in clinical settings and more feasible for assessments in larger sample sizes because it is more affordable, less complex and requires less preparation of the study site (9). For these reasons, qualitative assessment was the method of choice for this study.

Two physical therapists and two senior Physical Therapy students conducted the postural assessments. Thus, all evaluators had the required training to perform the tasks of the assessments. In addition, a specific eight-hour training was held for the evaluators, in order to ensure the standardization of data collection. The training consisted of discussing the assessment form, defining the postural deviations that would be analyzed and carrying out joint assessments. Divergences during the assessments were solved by consensus. Intra-evaluator reliability was previously tested in 10 subjects and the results showed an $80 \%$ agreement among measures.

The assessment was conducted by observation, and the data for each subject were recorded on standardized assessment forms. Posture assessment was performed in the anterior, posterior and lateral (right and left) views. We identified the main postural deviations in each view. In anterior view, we assessed elevation of the shoulders, elevation of the iliac crests and valgus knees. In the side view, we assessed forward head posture, thoracic hyperkyphosis and lumbar hyperlordosis. Finally, in the posterior view, we assessed the presence of winged shoulder blades.

Postural assessments were conducted using theoretical guidelines from Kendall et al. (1). According to these authors, in the posterior view, a plumb line can represent the gravity line in the mid-sagittal plane. Thus, it should ideally go between the legs from the midpoint between the heels, in the midline of the pelvis, over the spine and the center of the skull base. Also according to these guidelines, the right and left hemi-parts must be exactly symmetrical and, hypothetically offset one another. In the side view, the plumb line projection represents the gravity line in the frontal plane. The plumb line ends slightly in front of the lateral malleolus and also passes through most of the bodies of the cervical and lumbar vertebrae and the shoulder joint and slightly posterior to the frontal transverse axis of the hip joint. The presence of postural deviations was determined according to the positioning of the aforementioned structures in relation to the plumb line.

\section{Data Analysis}

The data were analyzed descriptively by calculating the proportion of individuals who had postural deviations according to age, gender, body mass index (BMI), handedness and physical activity.

BMI data were categorized as underweight (U), eutrophic (E), overweight (O) and obese (Ob), according to the BMI curves by age provided by the North American Center for Disease Control and Prevention (20).

Students were divided into three age groups. The choice of these age groups was based on the literature, so that the first group (6 - 9 years) was the prepuberty age group; the second group (10 - 12) was the female puberty age group and the third group $(13-15)$ was the male puberty age group $(21,22)$.

The statistical analysis was performed using the Statistical Package for Social Sciences software (SPSS). Multivariate analysis of variance was preceded by univariate analyses to identify significant associations $(\mathrm{P}<0.05)$ between the response variable and the factors. Univariate analysis was performed using the chi-square association test $\left(\chi^{2}\right)$.

The response variables used in the logistic regression analysis were all the postural deviations listed above and explanatory variables were age, gender, BMI, handedness and physical activity. We used a logistic regression model with logit link function for each postural deviation (response variable). For the selection of important variables, we used the stepwise selection method. All tests were two-tailed with the level of significance set at 5\%.

The sample size calculation was based on data on the prevalence of postural variations, considering a significance level of $5 \%$ and power of $80 \%$. The obtained sample was big enough for all postural deviations analyzed, except elevation of the shoulders, for which the calculation indicated a sample size of 340 
subjects. As the literature states with reference to the adequacy of the sample size that at least 25 individuals should be included for each predictor variable, the required sample size for multiple logistic regression analysis was met (23).

\section{Results}

Tables 2 and 3, respectively, show the prevalence of postural deviations according to the factors analyzed and the logistic regression results for significant associations.

Table 2 - Prevalence of postural deviations [n (\%)] according to age, gender, body mass index and physical activity. Values in bold indicate a significant association (in the chi-square test $\left.{ }^{[2]}\right]$ ) between the response variable (postural deviation) and the factor

\begin{tabular}{|c|c|c|c|c|c|c|c|c|}
\hline \multirow[b]{2}{*}{ Factors (n) } & & \multirow{2}{*}{$\begin{array}{l}\text { Forward } \\
\text { head } \\
\text { posture }\end{array}$} & \multicolumn{2}{|c|}{ Shoulder elevation } & \multicolumn{2}{|c|}{$\begin{array}{l}\text { Elevation of the iliac } \\
\text { crest }\end{array}$} & \multirow{2}{*}{$\begin{array}{l}\text { Valgus } \\
\text { knees }\end{array}$} & \multirow{2}{*}{$\begin{array}{c}\text { Winged } \\
\text { shoulder } \\
\text { blades }\end{array}$} \\
\hline & & & $\mathbf{R}$ & L & $\mathrm{R}$ & L & & \\
\hline \multicolumn{9}{|l|}{ Age (years) } \\
\hline $6-9$ & 104 & $37(35.6)$ & $32(30.8)$ & $34(32.7)$ & $25(24.0)$ & 15 (14.4) & $47(45.2)$ & $83(79.8)$ \\
\hline $10-12$ & 119 & $69(58.0)$ & 49 (41.2) & $44(37.0)$ & $48(40.3)$ & $16(13.4)$ & $54(45.4)$ & 78 (65.5) \\
\hline $13-15$ & 65 & 48 (73.8) & 17 (26.2) & $38(58.5)$ & $25(38.5)$ & $20(30.8)$ & $23(35.4)$ & $30(46.2)$ \\
\hline \multicolumn{9}{|l|}{ Gender } \\
\hline Female & 171 & $94(55.0)$ & $36(30.8)$ & $47(40.2)$ & $39(33.3)$ & $22(18.8)$ & 79 (46.2) & $102(59.6)$ \\
\hline Male & 117 & $60(51.3)$ & $62(36.3)$ & 69 (40.4) & $59(34.5)$ & $29(17.0)$ & $45(38.5)$ & 89 (76.1) \\
\hline \multicolumn{9}{|l|}{ BMI } \\
\hline UW & 27 & $18(66.7)$ & $11(40.7)$ & $9(33.3)$ & $11(40.7)$ & $7(25.9)$ & 9 (33.3) & $24(88.9)$ \\
\hline Normal weight & 217 & $120(55.3)$ & $73(33.6)$ & $89(41.0)$ & 78 (35.9) & $41(18.9)$ & $86(39.6)$ & $153(70.5)$ \\
\hline Overweight & 22 & $10(45.5)$ & $8(36.4)$ & $10(45.5)$ & $6(27.3)$ & $1(4.5)$ & $12(54.5)$ & $8(36.4)$ \\
\hline Obese & 22 & $6(27.3)$ & $6(27.3)$ & $8(36.4)$ & $3(13.6)$ & $2(9.1)$ & 17 (77.3) & $6(27.3)$ \\
\hline \multicolumn{9}{|l|}{ PA } \\
\hline Yes & 103 & $61(59.2)$ & $27(26.2)$ & $46(44.7)$ & $42(40.8)$ & $16(15.5)$ & $31(30.1)$ & $75(72.8)$ \\
\hline No & 185 & $93(50.3)$ & $71(38.4)$ & $70(37.8)$ & $56(30.3)$ & 35 (18.9) & $93(50.3)$ & $116(62.7)$ \\
\hline
\end{tabular}

Note: BMI: Body mass index; UW: underweight; PA: physical activity.

Table 3 - Multiple logistic regression results of postural deviations in relation to the factors associated with them in the univariate analysis

\begin{tabular}{|c|c|c|c|c|c|c|c|c|c|}
\hline \multirow{3}{*}{ Factors } & \multicolumn{9}{|c|}{ Postural deviations } \\
\hline & \multicolumn{3}{|c|}{$\begin{array}{l}\text { Forward head } \\
\text { posture }\end{array}$} & \multicolumn{3}{|c|}{ Shoulder elevation } & \multicolumn{3}{|c|}{$\begin{array}{l}\text { Elevation of the } \\
\text { iliac crest }\end{array}$} \\
\hline & $\mathrm{OR}$ & $95 \% \mathrm{Cl}$ & $p$ & $\mathrm{OR}$ & $95 \% \mathrm{Cl}$ & $p$ & $\mathrm{OR}$ & $95 \% \mathrm{Cl}$ & $P$ \\
\hline \multicolumn{10}{|l|}{ Age } \\
\hline $10-12$ & 0.18 & $0.09-0.34$ & 0.000 & 1.74 & $1.16-2.59$ & 0.007 & 0.23 & $0.12-0.44$ & 0.000 \\
\hline $13-15$ & 0.47 & $0.25-0.87$ & 0.016 & 3.58 & $2.32-5.52$ & 0.000 & 0.44 & $0.24-0.81$ & 0.009 \\
\hline \multicolumn{10}{|l|}{ Gender } \\
\hline Male & - & - & - & - & - & - & - & - & - \\
\hline \multicolumn{10}{|l|}{$\mathrm{BMI}$} \\
\hline Normal & 7.14 & 2.64-9.31 & 0.000 & - & - & - & 6.14 & $2.32-6.26$ & 0.000 \\
\hline Overweight & 3.03 & $1.78-5.16$ & 0.000 & - & - & - & 2.80 & $1.66-4.71$ & 0.000 \\
\hline Obese & 2.18 & $0.81-5.85$ & 0.124 & - & - & - & 1.08 & $0.39-2.98$ & 0.882 \\
\hline
\end{tabular}


Table 3 - Multiple logistic regression results of postural deviations in relation to the factors associated with them in the univariate analysis

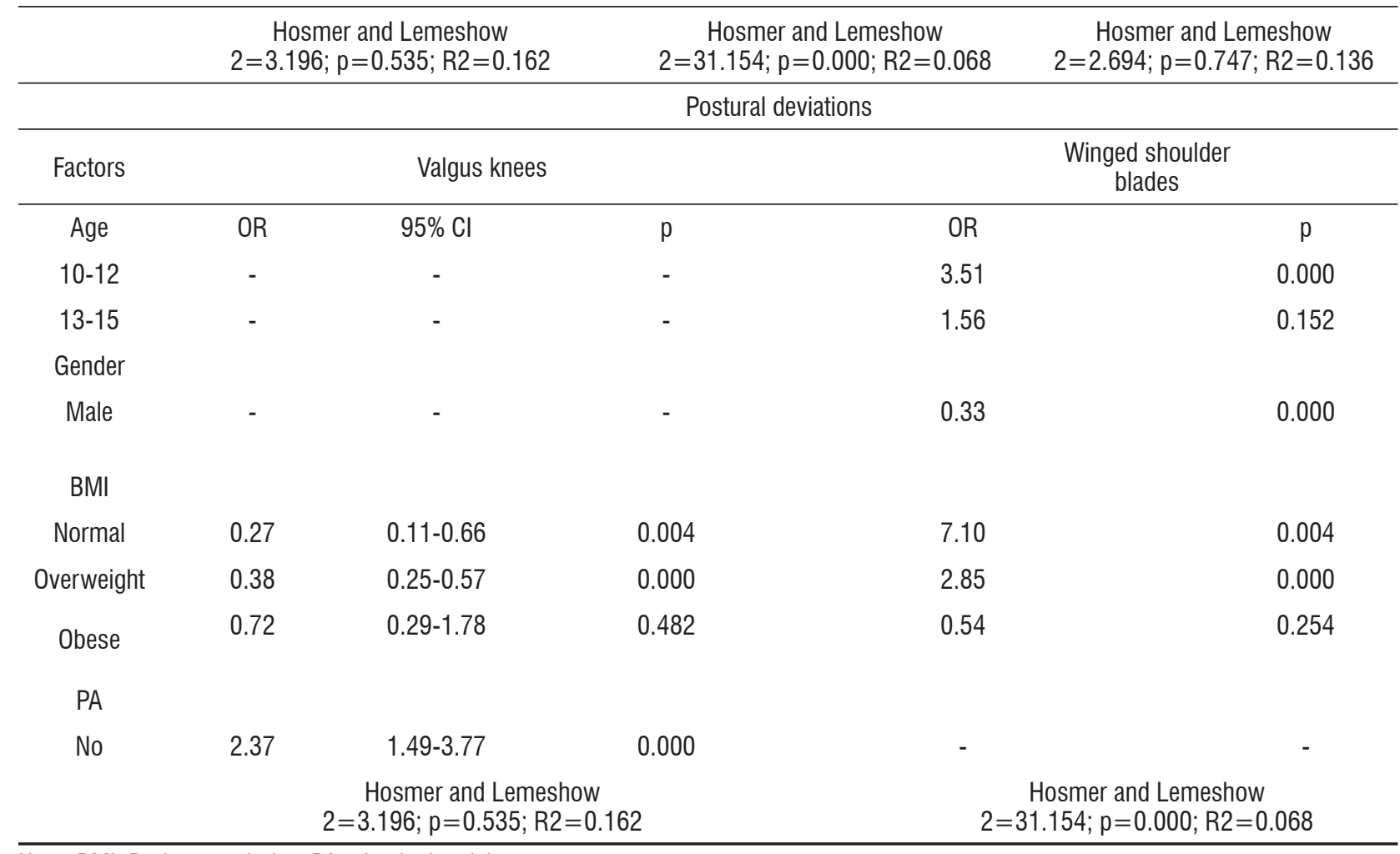

Note: BMl: Body mass index; PA: physical activity

There was a high prevalence of postural deviations in the sample studied. $53.5 \%$ of the 288 subjects had forward head posture; $74.3 \%$ had shoulder elevation; $51.7 \%$ had iliac crest elevation; $43.1 \%$ had valgus knees; $30.2 \%$ had thoracic hyperkyphosis; $37.2 \%$ had lumbar hyperlordosis; and $66.3 \%$ had winged shoulder blades.

The prevalence of thoracic hyperkyphosis and lumbar hyperlordosis were not associated with any of the analyzed factors. For this reason, they are not shown in Table 2. The same is true for handedness, which was not significantly associated with any of the postural deviations recorded.

The prevalence of winged shoulder blades was found to decrease with age

$(\mathrm{OR}=1.6)$, while the prevalence of forward head posture $(\mathrm{OR}=0.5)$, shoulder elevation (OR $=3.6$ ) and iliac crests elevation (OR $=0.4$ ) were found to be higher in the age group 13 - 15 years.

With regard to gender, we found a significant association only between gender and winged shoulder blades (OR $=0.3$ ). Male students had a higher prevalence of this postural deviation.

BMI was also associated with postural deviations. The forward head posture, elevation of the iliac crests, valgus knees and winged shoulder blades were associated with lower BMI, while the prevalence of valgus knee was associated with higher BMI. Physical activity was significantly associated with lower prevalence of valgus knees.

Regression analysis showed that winged shoulder blades were associated with factors such as age, gender and BMI, with $\mathrm{R}^{2}=0.34$. The other postural deviations were less prevalent in the sample, ranging from $7-16 \%$.

\section{Discussion}

This study aimed to assess the prevalence of postural deviations in children and adolescents, and to identify, using multiple logistic regression analysis, whether factors such as age, gender, BMI, hand dominance and physical activity are associated with these deviations. The results indicated a high prevalence of postural deviations among schoolchildren, especially forward head posture $(53.5 \%)$, shoulder elevation $(74.3 \%)$, iliac crest elevation (51.7\%), valgus knees (43.1\%), thoracic hyperkyphosis (30.2\%), lumbar hyperlordosis $(37.2 \%)$, and winged shoulder blades (66.3\%). 
Postural deviations usually occur in children of the same age group and most often do not require treatment $(24,25)$. Such deviations come in response to different balance requirements and different growth rates of body segments $(1,5)$. When the body reaches maturity, the balance of forces and the proportional growth of body structures generally lead to regression of postural deviations (1).

In this study, we found an association among age, BMI and forward head posture. The literature has reported that younger children have greater degrees of forward head posture (9). From a musculoskeletal standpoint, more mature children compensate in other regions of the spine and hip, minimizing abnormalities in the alignment of the head in relation to the trunk. However, in this study, the prevalence of forward head posture was higher in the age group of 13 to 15 years. It can be assumed that this change has been influenced by environmental factors. A previous study (26) has assessed the posture of elementary schoolchildren during classes and its relation to the inadequacy of the school furniture. The results have shown that $38 \%$ of the tables and $50 \%$ of the seats were too low for older students (8th graders). Thus, these children had to maintain a head and trunk flexion posture most of the time. Furthermore, the same study has shown that at least $10 \%$ of the time the flexion postures adopted were close to 30 degrees, posing risks to the children's health. Since children generally spend $30 \%$ of their awake time at school, the development of postural deviations may be associated with positions adopted in the classroom.

Shoulder elevation was associated with increased age. This indicates that this postural change arises during the growth phase, possibly due to the different growth rates of body segments. This asymmetry can also be associated with differences in overload between body sides, which is caused by external factors such as improper carrying of school supplies and asymmetrical sitting posture $(9,27)$. However, this postural change was not associated with handedness, although it was expected that the handedness might be associated with an elevation of the contralateral shoulder (1).

This study found that a high BMI and lack of physical activity were associated with higher prevalence of valgus knee, which is in line with the literature $(11,25)$. Also, according to these authors, these two factors may be interrelated. Most of the study participants who regularly performed physical activity did not have valgus knees. Since the most frequent physical activity is soccer, it can be assumed that the practice of this sport, which predominantly involves striking the ball with the medial aspect of the foot, might contribute to reduce of knee valgus loading. Resende et al. (28) have assessed 128 14-17-year-old boys who played and who did not played soccer. The authors have found that those boys who played soccer regularly had a prevalence of varus knees as high as $67.7 \%$ and a prevalence of valgus knees as high as $21.5 \%$. School boys who did not play soccer regularly had a prevalence of varus knees and valgus knees as high as $30.1 \%$ and $52.4 \%$, respectively.

On the other hand, physical activity might also be associated with lower body mass, which, in turn, is also associated with a lower prevalence of valgus knees. Silva et al. (10) have compared 24 obese and nonobese 9-17-year-old children and found a prevalence of knee deviations of $81.2 \%$ among obese children and of $22.2 \%$ among nonobese children.

According to the literature, valgus knees physiologically occur at age two years and reach peak incidence at age three years. The emergence of these deviations is associated with the search for a greater support base and for a greater balance when a child practices new movement strategies to improve his walking ability. From six to eight years of age this postural change tends to regress as a result of internal tibial torsion, longitudinal growth of the femur and disappearance of the inner tigh fat pad (5).

Obesity causes overload because of the overweight on the lower limbs, and leads to increased pelvic anteversion causing internal rotation of the hips. Especially in childhood, these factors, associated with the accumulation of fat in the inner thighs and the search for a greater support base, cause the malleoli to move apart. This, in turn, results in the opening of the medial compartment and increased pressure in the lateral knee compartment. With time and development, uneven growth occurs between the two compartments, leading to the emergence of a permanent valgus deformity of the knee $(5,29)$. In this study, we found an association between obesity and valgus knees, which indicates the need for preventive measures.

The prevalence of thoracic hyperkyphosis was not significantly associated with any of the assessed factors. Penha et al. (11) have found an increased prevalence of hyperkyphosis with increasing age. Thoracic hyperkyphosis was found in $21 \%$ of girls aged 7 years, $27 \%$ of girls aged 8 years, $45 \%$ of girls aged 9 years and 
$42 \%$ of girls aged 10 years. Cil et al. (30) have found an increase in the prevalence of thoracic hyperkyphosis among children up to 10 years of age, a decrease in its prevalence at ages 10 - 12 years, and a new increase at ages 13-15 years. However, in this latest study, the thoracic curvature has been quantitatively assessed and parameter of normality used has not been described, which makes data comparison difficult. Several authors have associated increased thoracic hyperkyphosis with the period of rapid growth in childhood and adolescence $(11,30)$, specially for females, who tend to hide their developing breasts by increasing kyphosis and forward protrusion of the shoulders (11).

The prevalence of winged shoulder blades decreased with increasing age, possibly due to muscle development, which leads to better attachment of the scapula to the thorax $(1,24)$. Penha et al. (9) have qualitatively assessed the posture of 191 seven- to ten-year-old children and found that $100 \%$ of the boys at age 7 years, 95\% at age 8 years and 93.8\% at age 9 years had winged shoulder blades. As in this study, the girls in the aforementioned study had lower prevalence rates, namely $71.8 \%$ at age 7 years, $71 \%$ at age 8 years and $66.7 \%$ at age 9 years. According to Asher (5), girls reach their maximum muscle force earlier than boys because in girls the sexual maturation process begins earlier than in boys.

Although this study has shown significant associations, it has some important limitations such as its crosssectional design. It would be relevant to conduct a longitudinal follow-up of these children to assess the progress of these deviations throughout the children's development. However, despite the study design, the fact that the number of children per age group was relatively homogeneous allows us to assume that the age groups used provide a relatively consistent notion of development.

\section{Conclusion}

The findings of this study contribute to a better understanding of this topic, because they allowed us to identify the relationship between postural deviations and factors such as age, gender, BMI, handedness and physical activity, using logistic regression analysis. These findings also contribute to the understanding of how and why these deviations develop, and to the implementation of preventive and rehabilitation programs, given that some of the analyzed factors, such as BMI and physical activity, are modifiable. Future prevention and rehabilitation programs should take these aspects into account, in order to avoid adult structural problems that can be prevented in childhood and adolescence.

\section{References}

1. Kendall FP, Mccreary EK, Provance PG. Músculos provas e funções. Barueri (Brazil): Manole; 2007.

2. Levangie P, Norkin C. Joint structure and function: a comprehensive analysis. Philadelphia: F. A. Davis Company; 2005.

3. Detsch C, Luz MH, Candotti CT, Oliveira DS, Lazaron F, Guimarães LK, et al. Prevalência de alterações posturais em escolares do ensino médio em uma cidade no Sul do Brasil. Rev Panam Salud Publica. 2007;21(4):231-8.

4. Detsch C, Candotti CT. A incidência de desvios posturais em meninas de 6 a 17 anos da cidade de Novo Hamburgo. Rev. Mov. 2001;7(15):43-56.

5. Asher C. Variações da postura na criança. São Paulo: Manole; 1977.

6. Lueder R, Rice V. Ergonomics for children: Designing products and places for toddlers to teens. Londres: Taylor \& Francis; 2008.

7. Juskeliene V, Magnus P, Bakketeig LS, Dailidiene N, Jurkuvenas V. Prevalence and risk factors for asymmetric posture in preschool children aged 6-7 years. Int J Epidemiol. 1996; 25(5):1053-9.

8. Penha PJ, João SMA, Casarotto RA, Amino CJ, Penteado DC. Postural assessment of girls between 7 and 10 years of age. Clinics. 2005;60(1):9-16.

9. Penha PJ, Casarotto RA, Sacco ICN, Marques AP, João SMA. Qualitative postural analysis among boys and girls of seven to ten years of age. Braz J Phys Ther. 2008;12(5):386-91.

10. Silva LR, Rodacki ALF, Brandalize M, Lopes MFA, Bento CB, Leite N. Alterações posturais em crianças e adolescentes obesos e não-obesos. Rev Bras Cineantropom Desempenho Hum. 2011;13(6):449-54 .

11. Penha PJ, Baldini M, João SMA. Spinal postural alignment variance according to sex and age in 7- and 8-year-old children. J Manipulative Physiol Ther. 2009;32(2):154-9. 
12. Zaina F, Atanasio S, Ferraro C, Fusco C, Negrini A, Romano $\mathrm{M}$, et al. Review of rehabilitation and orthopedic conservative approach to sagittal plane diseases during growth: hyperkyphosis, junctional kyphosis, and Scheuermann disease. Eur J Phys Rehabil Med. 2009;45:595-603.

13. Johnson J, Deshpande C. Health education and physical education: disciplines preparing students as productive, healthy citizens for the challenges of the 21st centrury. J Sch Health. 2000;70(2):66-8.

14. Noll M, Candotti CT, Vieira A. Escola postural: revisão sistemática dos programas desenvolvidos para escolares no Brasil. Rev Mov. 2012;18(4):265-91.

15. Guimarães MMB, Sacco ICN, João SMA. Caracterização postural da jovem praticante de ginástica olímpica. Braz J Phys Ther. 2007;11(3):213-9.

16. Arruda MF. Análise postural computadorizada de alterações musculoesqueléticas decorrentes do sobrepeso em escolares. Motriz. 2009;15(1):143-50.

17. Juul-kristensen B, Fallentin N, Ekdahl C. Criteria for classification of posture in repetitive work by observation methods: A review. Int J Ind Ergon. 1997;19:397-411.

18. Batistão MV, Carnaz L, Barbosa LF, Motta GC, Sato TO. Posture and musculoskeletal pain in eutrophic, overweighed, and obese students. A cross-sectional study. Motriz. 2014;20(1):192-9.

19. Teixeira FA, Carvalho GA. Confiabilidade e validade das medidas da cifose torácica através do método flexicurva. Braz J Phys Ther. 2007;11(3):199-204.

20. Centers for Disease Control and Prevention (CDC). About BMI for Children and Teens. 2011 [cited 2013 Sep 19]. Available from: http://tinyurl.com/yewbvqf.

21. Rodrigues S, Montebelo IL, Teodori RM. Distribuição da força plantar e oscilação do centro de pressão em relação ao peso e posicionamento do material escolar. Braz J Phys Ther. 2008;12(1):43-8.

22. Rogol A, Roemmich J, Clark P. Growth at puberty. J Adolesc Health. 2002;31:192-202.

23. Bagley $\mathrm{S}$, White $\mathrm{H}$, Golomb BA. Logistic regression in the medical literature: Standards for use and reporting, with particular attention to one medical domain. J Clin Epidemiol. 2001;54:979-85.
24. Mac-thiong JM, Berthounnaud E, Dimar JR, Betz RR, Labelle H. Sagittal alignment of the spine and pelvis during growth. Spine. 2004;29(15):1642-7.

25. Lafond D, Descarreaux M, Normand MC, Harrison DE. Postural development in school children: a cross-sectional study. Chiropr Osteopat. 2007;15:1.

26. Batistão MV, Sentanin AC, Moriguchi SC, Hansson GA, Coury HJCG, Sato TO. Furniture dimensions and postural overload for schoolchildren's head, upper back and upper limbs. Work. 2012;41:4817-24.

27. Trevelyan F, Legg S. Back pain in school children where to from here? Appl Ergon. 2006;37(1):45-54.

28. Resende LFM, Santos M, Araújo TL, Matsudo VKR. A prática do futebol acentua os graus de geno varo? Rev Bras Med Esporte. 2011;17(5):329-33.

29. Brandalize M, Leite N. Alterações ortopédicas em crianças e adolescentes obesos. Fisioter Mov. 2010;23(2):283-8.

30. Cil A, Yazici M, Uzumcugil A, Kandemir U, Alanay A, Alanay Y, et al. The Evolution of Sagittal Segmental Alignment of the Spine During Childhood. Spine. 2004;30(1):93-100.
Received in 01/19/2015

Recebido em 19/01/2015

Approved in 12/03/2015

Aprovado em 03/12/2015 
